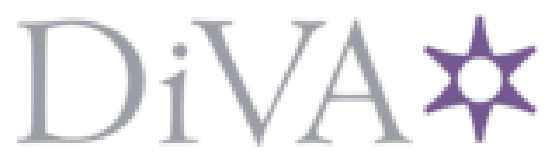

http://www.diva-portal.org

This is the published version of a paper published in Sport Science Review.

Citation for the original published paper (version of record):

Thedin Jakobsson, B., Lundvall, S., Redelius, K. (2014)

Reasons to stay: A study of 19 year old Swedish club sport participants.

Sport Science Review, 23(5-6): 205-224

http://dx.doi.org/10.1515/ssr-2015-0002

Access to the published version may require subscription.

N.B. When citing this work, cite the original published paper.

Permanent link to this version:

http://urn.kb.se/resolve?urn=urn:nbn:se:gih:diva-3634 


\title{
Reasons to Stay in Club Sport According to 19-Year-Old Swedish Participants: A Salutogenic Approach
}

\author{
Britta Thedin JAKOBSSON ${ }^{1} \cdot$ Suzanne LUNDVALL ${ }^{1}$ \\ Karin REDELIUS ${ }^{1}$
}

\begin{abstract}
A vital part of many teenagers' lives is participation in club sports. ADespite this, many adolescents drop out of club sports. Since physical inactivity is increasing among young people, this is of great political concern. One aim of this study is to explore why young people in their late teens continue to participate in organized club sports. Another aim is to examine the perceived levels and intensity of physical activity among participants and non-participants $(n=377)$. The results show that primary reasons to continue participating in club sports are having fun and the sense of enjoyment, the sense of belonging, and the sense of improving sport skills. Of lesser importance, however, is the desire to compete. A large amount of club sports participants $(74 \%)$ report that they are regularly physically active in an intense form of exercise compared to a significantly smaller amount $(12 \%)$ of non-participants. The findings are discussed in relation to Aaron Antonovsky's salutogenic approach and his concepts of sense of coherence (SOC).
\end{abstract}

Keywords: youth sports, club sports, participation, Antonovsky, sense of coherence

\footnotetext{
1 The Swedish School of Sport and Health Sciences, Stockholm, Sweden
} 


\section{Introduction and background}

The dropout rate from club sports among teenagers is of great political concern in Sweden, as it is in many countries. During the last decade, the Swedish government has allocated additional money to local sports clubs belonging to the Swedish Sport Confederation ${ }^{2}$ in order to stimulate more young people participating in club sports (Peterson, 2008). Not much attention has been directed toward examining what stimulates teenagers to continue with club sports. Research has mostly been concerned with the opposite question: Why do they stop? Decreasing club sports participation has been highlighted in a number of studies (Coakley, 2003; Coakley \& Pike, 2009; De Knop, Engström \& Skirstad, 1996; Pilgaard, 2012; Seabra, Mendonca, Thomis, Malina \& Maia, 2007; Seippel, 2005; Scheerder, Taks, Vanreusel \& Renson, 2002). A variety of causes for dropping out have been detected: conflicts of interest, lack of fun, perception of low abilities (Cervelló, Escarití \& Guzmán, 2007; Weiss \& Amorose, 2008), injuries (Klint \& Weiss, 1986), perception that sports are too time-consuming, factors related to disliking pressure or not getting along with teammates (Carlman, Wagnsson \& Patriksson, 2013), conflicts with coaches, lack of playing time (Weiss \& Williams, 2004), and negative factors related to early specialization (Wall \& Côté, 2007).

Not all youth drop out, however; some stay on. In this article we will examine reasons for youths to continue and what meaning club sports hold for those who are still participating in their late teens. Such a focus is in line with the research question posed by Antonovsky, a noted sociologist. Instead of studying why people become ill, Antonovsky used a salutogenic approach and explored why they stay healthy (1979). In other words, he concentrated on the processes and the resources for health and not the risks of disease (Antonovsky 1979, 1987). He claimed that the ability to comprehend one's situation in life and the capacity to use resources help explain why people in stressful situations manage to stay well. Our assumption is that a sense of coherence (with its component comprehensibility, manageability, and meaningfulness) is needed in order for a young person to remain in club sports. If young people consider their participation to be comprehensible (they understand the logic of sports), manageable (they can do what is required; they accept the conditions and rules), and meaningful (they are motivated and like what they are doing), it is more likely that they will stay on (see also author, 2014).

\footnotetext{
${ }^{2}$ The Swedish Sports Confederation (RF) is the country's largest popular and non-profit movement with around 22,000 sports clubs and 600,000 voluntary leaders with many teenage participants (The Swedish Sports Confederation, 2009). Although the Confederation is an independent non-governmental organization, it is dependent on public financial support. It has been a part of the development of the welfare state and Swedish welfare policy since the beginning of the 20th century (Bergsgard \& Norberg, 2010).
} 
A question that can be put forward is whether it is important that teenagers continue participating in sport clubs. Today there are many opportunities to be physically active outside of school and clubs. Various gyms, fitness or training institutes, and similar commercial places exist, as well as less costly alternatives, like jogging trails and places for non-organized activities (skateboarding, free running, biking, etc.). However, whether older teenagers use these alternatives regularly to the extent that they perceive themselves to be physically active on an intense level, is less known. Therefore, in addition to examine the meaning of club sport participation for teenagers that continue, we will also compare how club sport participants and non-participants perceive themselves in relation to level and intensity of physical activity.

Understanding sports participation is a complex issue. A number of factors have been suggested to influence adult participation, such as age constraints, gender-specific norms that affect the participation rates more for men than women, education level, and socioeconomic positions, as well as childhood experiences that lead to a broad or narrow movement repertoire in adulthood (Engström, 2008; Scheerder, Vanreausel \& Tasks, 2005; Scheerder, et al., 2002). Children's participation studies reveal that some reasons for being engaged in club sports at a young age are social dimensions, as well as enjoyment and feeling healthy (Allander, Cowburn \& Foster, 2006; Light, Harvey \& Memmert, 2013; MacPhail, Gorley \& Kirk, 2003). Fewer studies have focused on why older teenagers participate. Skille and Østerås (2011) found that fun is the number one reason for doing sports, but the definition of "fun" varied. One explanation was linked to social aspects, another to health, and a third to competitiveness. Consequently, they found that a mixture of preferences that may relate to both intrinsic and instrumental values explained young people's sports participation. In a qualitative interview study, Author (2014) found somewhat different results. Youths in their mid-teens who continued in club sports highlighted that development and learning skills were important for staying on. Although some teenagers found competition to be challenging, it was seldom put forward as a meaningful component. These results have implications for how club sports should be organized in order to attract more young people, but they derive from a small sample. In this article, reasons for staying are examined among a large number of 19 -year-old club sports participants.

\section{A salutogenic approach}

The study is inspired by Aaron Antonovsky's salutogenic approach and his model sense of coherence (SOC), which includes the components comprehensibility, manageability, and meaningfulness (Antonovsky, 1979, 1987). The first one, comprehensibility, should be understood as the extent to which 
events are perceived as making logical sense, that they are ordered, consistent, and structured. Antonovsky (1987) noted, “The stimuli deriving from one's internal and external environments in the course of living are structured, predictable and explicable" (p. 19). It is through experiences perceived as coherent and structured that comprehensibility is formed.

The second element, manageability, concerns the extent to which a person feels that he or she can cope. Manageability relates to the resources people feel they have to meet the demands made and the challenges set in the situation they are in (Antonovsky, 1987). Resources can be artifacts such as physical tools and equipment, but they can also include social and cultural capital, such as social relations, matching skills in the form of motor skills, or mental and cognitive abilities. A good sense of manageability is shaped by a balance between the demands and the resources that the individual has access to.

Antonovsky's third element of SOC is labeled meaningfulness and relates to how much one feels that life makes sense and that challenges are worthy of commitment. Meaningfulness, which Antonovsky also calls the "motivational component," is considered the most important component in the SOC context. Meaningfulness constitutes "these demands that challenges are worthy of investment and engagement" (Antonovsky, 1987, p. 19). It is about feeling a positive expectation of life and the future. Antonovsky stresses that SOC is not primarily concerned with the cognitive aspects but rather with the experience of being involved, engaged, and dedicated to situations in life (in club sports in this study).

Antonovsky's main argument is that salutogenesis depends on experiencing a strong sense of coherence. Furthermore, human resources and the conditions of the living context result from the interaction between an individual and the structures of society (Antonovsky, 1979, 1987; Eriksson, 2007). Antonovsky's salutogenic theory and the SOC model have been used in Swedish research on health and resilience as well as in health-promoting work with teenagers (Eriksson, 2007; Hagström, Redemo \& Larsson, 2000; Quennerstedt, 2008). The fact that the study was inspired by Antonovsky means that we have taken the liberty to interpret and utilize his concept for the context of this study when posing the research question and when discussing the answers from the teenagers.

Inspired by the salutogenic approach, the aim in this article is to illuminate the meaning of club sports among 19-year-old participants and to explore perceived level and intensity of physical activity among 19-year-old club sport participants and non-participants. 


\section{Study design and analysis}

This study is part of a longitudinal and multidisciplinary project in which a total of 1,976 students aged 10,13, and 16 from 48 randomly selected Swedish schools participated (Engström, 2004). The study is based on the follow-up of the base study's original 10-year-old children (born in 1991), who continued to be monitored at the ages of 13 (in 2004), 16 (in 2007), and 19 (in 2010). In the first data collection (2001), 579 of 642 (90\%) 10-year-olds took part, and this study focuses on those individuals born in 1991 who were 19 years old at the onset of the data collection in 2010. In the study presented in this article, 377 of 579 (194 girls and 183 boys) 19 -year-olds answered, which is $65 \%$ of the base study respondents. The 2001 base study was carried out in situ in Stockholm, Gothenburg, and Malmö. In the follow-up study, which this paper draws on, the questionnaire was sent out by post.

In the dropout analysis, the responses from those who participated in the study in 2010 were compared to those who did not take part in 2010 but who participated in 2001, 2004, and 2007. The analysis showed no significant differences between 2001 and 2004 but significant differences for 2007. Ten percent more of those who were participants in club sports in the 2007 survey responded in 2010. Therefore, the survey group is somewhat selective regarding the participation rate in club sports, but this should not affect the questions raised in this article.

The questionnaire and measurements. The questionnaire was created and checked by a team of researchers and submitted to tests for reliability and validity (Author, et al., 2012; Brun Sundblad, 2006; Ekblom, 2005; Engström, 2004). The test-retest reliability of the survey was carried out in the spring of 2007 with a class of 16-year-old students, from which a correlation of 0.87 was obtained with regard to the key issues of the extent of physical activity. Before the study started, parental permission was obtained, and ethical guidelines were followed. Each study was approved by the Ethical Committee at Karolinska Institutet, Stockholm (Ref. no. 00-416).

The questionnaire items that are of interest in this study concern club sports participation and perceived level and intensity of physical activity. There were 133 respondents (35\%) who considered themselves to be club sports participants. In order to compare the answers, two variables were created: participants in club sports $(\mathrm{n}=133$, girls $=61$ and boys $=72)$ and non-participants $(\mathrm{n}=244$, girls $=133$ and boys $=111)$. No statistical differences were obtained between the number of boys and girls participating in club sports. 
In order to measure perceived level and intensity of physical activity, the respondents answered two slightly different questions. The first was "Which person do you resemble the most?" (Ekblom, 2005; Engström, 2004). Five answer alternatives were given.

I'm a person who:

A. exercises very little; breath;

B. exercises quite a lot but never to the extent of getting sweaty or out of

C. exercises quite a lot and sometimes I get sweaty and out of breath;

D. exercises so that I get sweaty and out of breath several times a week;

E. exercises so that I get sweaty and out of breath every day or almost every day.

The second question was "How much physical activity have you done regularly during your leisure time in the last year?" (Compare with Ekblom, 2005; Engström, 2004, 2008). The options for answering were as follows:

A. No or almost no physical activity but sometimes a walk or similar activity; stairs;

B. Some everyday physical activity like walking to the bus or walking the week;

C. Deliberate light physical activity, e.g., walking or biking, at least once a

D. Deliberate moderate to vigorous exercise, e.g., fast walking, jogging, or swimming, at least once a week;

E. Deliberate intense and exhausting exercise, training, or competition, e.g. running, fitness training, or ball games, regularly every week.

The analysis. For the statistical analysis, the questionnaires were converted into a database using the SPSS (Statistical Package for the Social Sciences, SPSS 21.0, Chicago, IL, USA) computer software. By way of qualitative control, the questionnaires were reread and compared with databases to achieve the highest possible level of accuracy. In order to determine whether there were any differences between participants and non-participants in club sports regarding perceived level and intensity of physical activity, a chi-square was used to examine group differences with the following level of statistical significance: $\mathrm{p}<0.05\left(^{*}\right)$, $\mathrm{p}<0.01(* *)$, and $\mathrm{p}<0.001(* * *)$.

In order to explore club sports participation and the reasons for staying in club sports at the age of 19, the club sport participants were asked to answer the following question: "If you are still participating in club sports, what are the 
reasons that you continue?" Of the 133 club sport participants, 118 persons $(89 \%)$ gave one or more reasons why they continued with club sports. In total, 190 statements about reasons to continue were given by the participants.

On the basis of the answers, the phrases were listed so that the process of grouping them into themes could begin (Patton, 2002). To categorize statements, the SOC components, as described earlier (see also Antonovsky, 1987), served as analytic tools that were "good to think with." More precisely, expressions associated with the SOC components of meaningfulness, such as participation, involvement, enjoyment, solidarity, interest, motivation, and belief in the future, were utilized in the analysis (Antonovsky, 1979, 1987; Hagström, Redemo \& Larsson, 2000; Cederblad \& Hansson, 1996). These expressions are also the foundation of the component of meaningfulness (Antonovsky, 1987). However, the components are not separate elements but rather are intertwined and related to the total situation of the respondents' sports participation (see also Antonovsky, 1979).

\section{Findings}

The result section starts with an analysis of the meaning of participation in club sports and ends with the comparison of club sports participants' and nonparticipants' perceived level and intensity of physical activity.

The meaning of participation. In the following, we present the four themes that emerged in the analysis of the empirical data consisting of 190 statements from the open-ended question about the participants' reasons to continue with club sports. The numbers of excerpts included in each category are written in brackets afterward. The themes are labeled a) the sense of fun $(79), b)$ the sense of belonging when being a part of a group (49), c) the sense of being healthy and looking good (38), and d) the sense of improvement and development (24).

The sense of fun when doing club sports (79). In almost 80 of the statements, the respondents noted that they participated in club sports because "doing sports is fun." This was by far the most common answer, and descriptions of sporting activities as fun and enjoyable are in line with the findings of previous studies of children (Light \& Lémonie, 2010; Light, Harvey \& Memmert, 2013; MacPhail, Gorely \& Kirk, 2003; Trondman, 2005; Wankel \& Kreisel, 1985) as well as teenagers (Author, 2014; Skille \& Østerås, 2011). According to Côté and Hay (2002) and Franzén and Peterson (2004), young people drop out when they no longer experience sports as being fun, but what "fun" means is seldom analyzed (see, e.g., MacPhail, Gorely \& Kirk, 2003; Klint \& Weiss, 1986). 
Since our intention was to gain a deeper understanding of why teenagers continue participating in club sports, we wanted to explore what it is that makes sports fun. Several aspects of fun emerged that we consider to be closely related to meaningfulness, which contributes to a sense of coherence in the lives of the teenage participants. In this study, among the most frequent reasons for continuing with club sports were statements like "sport[s] [give me] enjoyment"; "it is fun to practice"; "it is fun, and I like having something to do"; and "badminton is the most enjoyable sport I have done in my whole life." Some participants stated that they had been doing sports for a long time and that sports was their hobby and almost like drugs to them: "I'm addicted to sports"; "it is intoxicating[; y]ou [either] can't [or] won't let it go." Often the statements concerned pleasurable feelings that were experienced through the body, a sense of "here and now" that was expressed in terms of feelings and not primarily as a cognitive aspect. It is a feeling that makes the experience strong and something the teenagers do not want to be without. Some respondents also expressed that it was more fun and enjoyable to participate in sports now than before since it was not as serious a practice as when they were younger.

In summary, participating in club sports gave participants opportunities to experience good feelings and a sense of enjoyment while engaging in a hobby. Fun and enjoyment also occur in the next theme, but the interaction and community with others are more emphasized in the empirical material.

The sense of belonging when being part of a group (49). A frequently given phrase for continuous participation in club sports was the opportunity to be involved with other people and to belong to a group. Participating with others and sharing experiences created good feelings. One girl wrote, "I like the community and the friendship in the club, and it is like a passionate hobby for me." Other statements were as follows: "sport is a big part of my life and it is a good feeling to belong to a team"; "it is fun to meet people and do things together." Friends, community, and fellowship were rephrased among the descriptions: "sports are very social"; "pleasant belonging to a group"; and "making friends in the group." Other studies concerning children show similar results (Allander, Cowburn \& Foster, 2006; Author, 2014; Coakley \& White, 1992; MacPhail, Gorely \& Kirk, 2003). Accordingly, a common reason to drop out is because friends do (Côté \& Hay, 2002; Franzén \& Peterson, 2004).

Many appreciated sharing moments together with others. These "others" could either be people of the participants' own age or people of different ages for whom club sports participation created an opportunity to meet. Phrases like "opportunities to meet new friends" and "you get a lot of friends by doing sports" were also common, as were "I like to be in a group and share the social 
values and community"; "when you practice in a group you get more team spirit and engagements."

Many answers were related to statements like: "I like to practice together with others"; "you are forced in a good way to practice when you are in a team or a training group"; "you go to practice since you know that there are others there waiting for you"; "it is easier to work out and practice together with others"; "I like having training peers." In other words, they emphasized that sports and physical activities were easier to do and more enjoyable if one does it in a club together with others. Then one does not have to arrange and decide what to do.

Closely linked to this sense of belonging was the enjoyment of being involved in a "group that likes to do the same things as you." In other words, sport clubs provide the possibility to experience a sense of belonging and to share a mutual experience. Club sports can be seen as meaningful because it is fun to meet peers, share experiences with others, and others are waiting for you and expecting you to participate.

The sense of being bealthy and looking good (38). One-third of the statements indicated that keeping physically fit and healthy were important reasons for continuing in club sports. These statements concerned improving cardiovascular conditioning, preventing disease or illness, keeping up one's concentration, strength, or just being able to relax and cope with life. Other statements stressed that sports and fitness training made the teenagers look good. Some noted, "I do fitness training because I am not satisfied with my body"; or "I want to lose weight." Obviously some had an interest in working out in club sports in order to keep in shape and improve their looks. Others did not mention the benefits of health in order to prevent illness or disease. Instead they focused on health from a holistic perspective, noting "a good feeling in both body and soul while doing sports." And they emphasized that they feel better in their whole body if they are physically active and that sports helps them to be active and exercise. Other words used to describe sports and physical activity included "wholesome" and "salutary," which is similar to what Eriksson (2007) suggested as a salutogenic approach to physical activity as a health-promotion arena. International studies also reveal that young people engage in sports because it makes them feel healthy (Allender, Cowburen \& Foster, 2006; MacPhail, Gorely \& Kirk, 2003; Light, Harvey \& Memmert, 2013; Skille \& Østerås, 2011).

The sense of improvement (24). The competitive part of club sports should, according to Côté and Hay's sports development model (2002) as well as the policy document of the Swedish Sports Confederation (2011), be emphasized after the age of 12 . Therefore, one would have expected that the teenagers 
should have put forward that they like to compete and be successful and that this was a main reason for continuing with club sports (see also Skille \& Østerås, 2011). However, only 5 out of 190 statements stressed this aspect: "I love to compete" or "I am a competitive person." Four of the participants stating this were apparently also very successful in what they were doing. Their goal was to become professional athletes. Their statements illustrate the so-called investment phase of club sports participation, according to Côté and Hay's sports development model (2002).

However, most expressions placed in this category emphasized the positive feeling of improvement, development, and learning new skills. They read as follows: "I like to become better"; "I like to develop my skills"; "I like to reach my personal goals"; or "I continue in order to learn new moves and skills." The learning of new things was also linked to fun and joy since some teenagers argued that developing and learning new skills were what made clubs sports fun. To be successful in competitions was seen as an acknowledgement that you have done your practice and developed your sports skills. The dominant practice in club sports, which is usually implicit, seems to require the teenager to compete if she or he wants to remain in some sports (e.g., most team sports) but not in others (e.g., aerobics, equestrian sports). To take part in competitions is something that teenagers who continue have to cope with and manage; otherwise, it could be difficult to continue. In ball games, for example, much of the training is executed in order to win matches. To compete and play are part of the game, but that was not what the teenagers in this study emphasized as reasons to continue.

Perceived level and intensity of physical activity. Now we will turn the attention to how participants $(\mathrm{n}=133)$ and non-participants $(\mathrm{n}=244)$ describe their perceived level and intensity of physical activity (Tables 1 and 2). The results in Table 1 show that there is a significant difference between the group of club sports participants and the group of non-participants. Table 1 shows results related to the following question: "What person do you resemble the most in terms of physical activity?" 
Table 1

Perceived level and intensity of physical activity among participants and non-participants in club sports. The internal dropout amounts to $1 \%$

\begin{tabular}{lccccc}
\hline $\begin{array}{l}\text { Which person do you resemble the } \\
\text { most? }\end{array}$ & $\begin{array}{c}\text { Club sports } \\
\text { Participant } \\
\mathrm{n}=133 \\
\%\end{array}$ & $\begin{array}{c}\text { Non-participant } \\
\mathrm{n}=244 \\
\%\end{array}$ & $\begin{array}{c}\text { Persons chi- } \\
\text { square Value }\end{array}$ & df & Sig. \\
\hline $\begin{array}{l}\text { I'm a person who } \\
\mathrm{A} .=\text { exercises very little }\end{array}$ & 4 & 11 & 83.7 & 4 & *** \\
$\mathrm{B}=$ exercises quite a lot but never to \\
$\begin{array}{l}\text { the extent of getting sweaty or } \\
\text { out of breath }\end{array}$
\end{tabular}

The results show that there is a significant difference between the respondents in the two groups. A vast majority, $77 \%$, of the club sports participants compared to $34 \%$ among the non-participants answered that they resemble someone who exercises so that they get sweaty and out of breath every day or several times a week (person D and E). A low portion $(5 \%)$ of the non-participants perceived themselves as someone who is physically active to the extent that they became sweaty and out of breath every day (person E), compared to one-third of the club sports participants.

Table 2 presents results relating to the following question: "How much physical activity have you done regularly during your leisure time in the last year?" 
Table 2

Perceived level and intensity of physical activity among club sports participants and nonparticipants. The internal dropout amounts to 1\%

\begin{tabular}{lccccc}
\hline $\begin{array}{l}\text { How much PA have you done } \\
\text { regularly during your leisure time the } \\
\text { last year? }\end{array}$ & $\begin{array}{c}\text { Club sports } \\
\text { Participant } \\
\mathrm{n}=133 \\
\%\end{array}$ & $\begin{array}{c}\text { Non-participant } \\
\mathrm{n}=244 \\
\%\end{array}$ & $\begin{array}{c}\text { Persons chi- } \\
\text { square Value }\end{array}$ & df & Sig. \\
\hline $\begin{array}{l}\text { A. No or almost no physical activity } \\
\text { but sometimes a walk or similar } \\
\text { activity. }\end{array}$ & 3 & 9 & 152.8 & 4 & *** \\
$\begin{array}{l}\text { B. Some everyday physical activity } \\
\text { like walking to the bus or walking the } \\
\text { stairs. }\end{array}$ & 4 & 29 & & \\
$\begin{array}{l}\text { C. Deliberate light physical activity } \\
\text { e.g. walking or biking, at least once. }\end{array}$ & 3 & 21 & & \\
$\begin{array}{l}\text { D. Deliberate moderate to vigorous } \\
\text { e.g. fast-walking, jogging or } \\
\text { swimming, at least once a week. }\end{array}$ & 16 & 28 & & \\
$\begin{array}{l}\text { E. Deliberate intense and exhausting } \\
\text { exercise training or competitions, } \\
\text { e.g. running, fitness training, or ball } \\
\text { games regularly every week }\end{array}$ & 74 & & & & \\
\hline
\end{tabular}

The results in Table 2 also show that there is a significant difference between the two groups. When asked about regular physical activity habits during leisure time the last year, $90 \%$ of the club sports participants answered that they had been active on an intense level at least once a week (D and E), compared to $40 \%$ of the non-participants. A significantly higher proportion, $74 \%$ of those participating in club sports, reported that they had been physically active on an intense level several times a week during the last year compared with $12 \%$ of the non-club participants. Apparently club sports participants perceive themselves as being physically active regularly and on an intense level to a significantly higher degree than non-participants.

\section{Discussion and conclusion}

The aim of the study presented in this paper was to explore what 19-yearolds find important and meaningful in club sports participation. It also examined perceived level and intensity of physical activity among participants in relation to non-participants in club sports. The discussion that follows is inspired by Antonovsky's salutogenic framework in order to provide a deeper understanding of why teenagers participate in club sports. In the light of recent efforts by 
Western societies to increase physical activity among children and adolescents (Malina, 2001; WHO, 2007; Kirk, 2005; Peterson, 2008), we will also give some suggestions for how club sports should be carried out to attract more young people.

What makes participants in their late teens continue with club sports? A number of reasons emerge when young people give voice to their choice to engage in a club. Drawing from the responses, the teenagers continue because they think sports are fun and participation gives them a sense of enjoyment, a sense of belonging when being part of a group, a sense of being healthy and looking good, and a sense of improving and developing sporting skills. Few stressed that they continue because they wanted to compete, succeed, or become an elite athlete. Instead it is a lot about having fun-that was the most common answer-which also includes enjoyment and engagement in a taskoriented community with others. We believe that fun is closely linked to what Antonovsky (1987) called meaningfulness. Having a hobby, in this case doing sports, is seen as an important factor for people in order to perceive well-being (Hagström, Redemo \& Larsson, 2000).

Other common answers emphasized the sense of belonging and the good feeling of being part of a group. It seems as if practicing sports contributes to strengthening the respondents' means of handling situations together with others. The club sports participants' sense of belonging emerges as a link to the meaning of social and recreational values. This is also closely linked to Antonovsky's component of meaningfulness (Antonovsky, 1987). But the feeling of belonging does not automatically arise from sports participation alone. A feeling of being a worthy participant and accepted for who you are is crucial (Lundvall \& Walseth, 2013). And sports participation helped the club sports participants to structure their lives, keep fit, relax, and feel healthy. In this way, club sports participation fulfills several desires in the young people's lives. Club sports participation makes life more manageable in total (see, e.g., Antonovsky, 1987; Hagström, Redemo \& Larsson, 2000).

To have fun and be together with others are reasons for staying that are in line with what Skille and Østerås (2011) called intrinsic values. But contrary to their and others' findings (Skille \& Østerås, 2011; MacPhail, Gorely \& Kirk, 2003), instrumental values, like competitiveness and health, were not especially stressed in this study.

We will now turn to the questions about the perceived level and intensity of physical activity. The results showed that the 19-year-old respondents who were active in club sports perceived themselves as physically active regularly and on a vigorous level to a significantly higher degree than non-participants. 
Although there are opportunities to be physically active outside clubs in gyms, dance, or training institutes or on your own in non-organized activities, few nonparticipants perceived themselves as active as the participants did. We believe that the explanation for this can be found in the reasons the participants gave for staying-especially the category labeled "The sense of belonging when being a part of a group." This is important when interpreting why club sports participants perceive themselves as more physically active than non-participants. In this study, the teenagers who did club sports emphasized that they appreciated training together with others, belonging to a group, and knowing that other people you know will be at the training session. Some actually highlighted that it is easier to do sports and physical activities if you do it in a sports club together with others, so you do not have to arrange and decide what to do by yourself. For those who were non-club sports participant, this option is not available to the same extent. For non-participants, it is to a great extent up to the individuals to be physically active. Many non-participants have to make an active choice and decide what kind of physical activity to engage in, where, when, and maybe also with whom. For many club sports participants, this is already arranged-they just go to the training or workout session and they know they will meet others with the same interests. In that sense, the title of this article, "Reasons to Stay," not only points at young people's reasons for staying but also to a question of political concern. If we want young people to live an active life, then this is a reason to make them want to stay and continue supporting sport clubs.

The conclusion is that doing sports seems to be manageable, comprehensible, and meaningful to the group of teenagers who are continuers, but what is meaningful seems to differ in some aspects. The promotion of club sports, as one way for teenagers to become physically active, obviously considers new forms of how to organize sports, with less focus on competition as the tool for creating feelings of belonging. Previous studies have suggested that children's sports (ages 6-12) should involve increasing deliberate play and emphasize development, fun, and enjoyment (Côté \& Hay, 2002; Côté, Coakley \& Bruner, 2012; Siedentop, 2002). The teenagers in this study participate in and appreciate sports, not least for the opportunity to have fun, belong to a group, and develop together with others. To be a part of a sports club and to be physically active might give the participants a sense of coherence for the moment (see, e.g., Hagström, Redemo \& Larsson, 2000). Therefore, we suggest that sports clubs should try to organize activities that emphasize development and improvement of skills with numerous opportunities and challenges for motor and social learning instead of competition as the only focal point. Quennerstet (2008) suggested that PE could use a salutogenic approach in relation to teaching and content knowledge in PE. Maybe coaches in club sports could use the same approach? A wise and well-conducted sports practice can stimulate the development of processes 
and resources that underpin both manageability and comprehensibility in order to increase opportunities to participate in physical activity and sports. By employing an approach in which questions are asked about what teenagers need to understand, manage, and experience as meaningful in sports, more young people will have opportunities and find reasons to stay and participate longer.

\section{References}

Allander, S., Cowburn, G., \& Foster, C. (2006). Understanding Participation in Sport and Physical Activity Among Children and Adults: A Review of Qualitative Studies. Health Education Research Theory \& Practice, 21(6), 826-835.

Antonovsky, A. (1979). Health, Stress and Coping. San Francisco, CA: Jossey-Bass.

Antonovsky, A. (1987). Unraveling the Mystery of Health. San Francisco, CA: JosseyBass.

Bergsgard, N. A. \& Norberg. J. (2010). Sport Policy and Politics - The ScandinavianWay. Sport in Society, 13(4), 567-582.

Brun Sundblad G. (2006) Perceived Health in Swedish School Students: A longitudinal prevalence study. Thesis for doctoral degree, Karolinska Institutet, Stockholm.

Carlman, P., Wagnsson, S. \& Patriksson, G. (2013) Causes and consequences of dropping out from organized youth sport. Swedish Journal of Sport Research, 1, 26-54.

Cederblad, M. \& Hansson, K. (1995). Känsla av sammanhang, studier frän ett salutogent perspektiv. [Sense of Coherence, a study from a salutogenic perspective] Lund: Lund Insitutionen för barn och ungdomspsykiatri.

Cervelló, E. M., Escartí, E. \& Guzmán, J. F. (2007). Youth sport dropout from the achievement goal theory. Psicothema, 19, 65-71.

Coakley, J. (2003). Sports and children. Are organized programs worth the effort? in Coakley, J. (ed) Sport in Society: Issues \& Controversies. 8th ed. New York: McGraw Hill.

Coakley, J. \& Pike, E. (2009). Sport in Society: Issues and Controversies. New York: McGraw-Hill Education. 
Coakley, J. \& White, A. (1992). Making Decisions: Gender and Sport Participation Among British Adolescents. Sociology of Sport Journal, 9, 20-35.

Côte', J., Coakley, C. \& Bruner, M. (2012) 'Children's Talent Development in Sport: Effectiveness or Efficiency?', in Dagkas, S., and Armour, K. (eds) Inclusion and Exclusion Through Youth Sport, 172-185. London: Routledge.

Côte', J. \& Hay, J. (2002). 'Children's Involvement in Sport: A Development Perspective.', in Silva, J. \& Stevens, D. (Eds) Psychological Foundations of Sport, pp. 484-502. Boston, MA: Allyn and Bacon.

De Knop P., Engströ L.-M., \& Skirstad, B. (1996). 'Worldwide trends in youth sport.', in De Knop P., Engström L.-M., Skirstad B. \& Weiss, M. R. (Eds) Worldwide Trends in Youth Sport Champaign, IL: Human Kinetics, 276-281.

Ekblom, Ö. (2005). Physical Fitness and Overweight in Swedish Youths. Dissertation, Karolinska Institutet: Stockholm, Sweden.

Engström, L.-M. (2004). Skola - Idrott - Hälsa Studier av ämnet idrott och hälsa av barns och ungdomars fysiska aktivitet, fysiska kapacitet och bälsotillständ. Utgängspunkter, syfte och metodik. Rapportserie nr 1 i serien Skola - Idrott - Hälsa. [SchoolSports- Health. Studies of physical education as well as children and adolescents' physical activities, physical capacity and health status. Starting points aims and methodology. Report no.1]. Stockholm: The Swedish School of Sport and Health Sciences.

Engström, L.-M. (2008). Who is physically active? Cultural capital and sports participation from adolescence to middle age - a 38 year follow-up study. Physical Education and Sport Pedagogy, 13(14), 319-343.

Eriksson, M. (2007). Unravelling the mystery of salutogenesis Avhandling: the evidence base of the salutogenic research as measured by Antonovsky's sense of coherence scale. Turku: Helsinki: Diss. Åbo akademi. Folkhälsan research centre, health promotion research programme.

Franzén, M. \& Peterson. T. (2004). Varför lämnar ungdomar idrotten? En undersökning av fotbollstjejer och - killar fran 13 till 16 ar [Why do youth leave sport? A survey of soccer girls and boys from 13 to 16 years of age]. Riksidrottsförbundet. FoU-rapport 2004:3. Stockholm: Riksidrottsförbundet.

Hagström, U., Redemo, E. \& Larsson, G. (2000). När självkänslan växer ... Ett inspirationsmaterial för ett hälsofrämjande arbete på gymnasieskolans individuella program. 
Erfarenheter frän ett pilotprojekt [When self-esteem grow...An inspirational material for health promotion in high school individual programs]. Stockholm: Folkhälsoinstitutet, Rapport 19.

Kirk, D. (2005). Physical Education, Youth Sport and Lifelong Participation: The Importance of Early Learning Experiences. European Physical Education Review, 11(3), 239-255.

Klint, K. \& Weiss, M. (1986). Dropping in and Dropping Out: Participation Motives of Current and Former youth Gymnasts. Canadian Journal of Applied Sport Science, 11, 106-114.

Lundvall, S. \& Walseth, K. (2013). 'Integration and sports participation: Cultural negotiations and feelings of belonging'. in Women and sport, Scientific Report Series http://www.sisuidrottsbocker.se/amnesomraden/kvinnorochidrott/ [accessed on November 2014].

Light, R., Harvey, S. \& Memmert, D. (2013). Why Children Join and Stay in Sports Clubs: Case Studies in Australian, French and German Swimming Clubs. Sport, Education and Society, 18(4), 550-560.

Light, R. \& Lémonie, Y. (2010). A Case Study on Children's Reasons for Joining and Remain in a French Swimming Club. Asian Journal of Exercise \& Sports, Science 7(1), 27-33.

MacPhail, A., Gorely, T. \& Kirk, D. (2003). Young People's Socialisation into Sport: A Case Study of an Athletics Club. Sport, Education and Society, 8(2), 251-267.

Malina, R. M. (2001). Tracking of Physical Activity Across the Lifespan. President's Council on Physical Fitness and Sports. Research Digest. Series, 3(14). Washington, DC: President's Council on Physical Fitness and Sports.

Patton, M. Q. (2002). Qualitative Research \& Evaluation Methods. 3edition. California: Saga Publication, Inc.

Peterson, T. (2008). Föreningsfostran och tävlingsfostran. En utvärdering av statens stöd till idrotten [An Evaluation of Government Financial Support to Sports Movement]. Stockholm: Fritzes.

Pilgaard, M. (2012). Teenageres idrætsdeltagelse i moderne hverdagsliv. Scandinavian sport studies forum, 3, 71-95. http:/ / sportstudies.org/wp-content/ 
uploads/2014/01/071-095_vol_3_2012_pilgaard.pdf [accessed on November 24 2014].

Quennerstedt, M. (2008). Exploring the Relation Between Physical Activity and Health - A salutogenic Approach to Physical Education. Sport, Education and Society, 13(3), 267-283.

Scheerder, J., Taks, M., Vanreusel, B., \& Renson, R. (2002). Social sport stratification in Flanders 1969-1999: intergenerational reproduction of social inequalities? International Review for Sociology of Sport, 37, 219-246.

Scheerder, J., Taks, M., Vanreusel, B., \& Renson, R. (2005). Social changes in youth sports participation styles 1996-1999: the case of Flanders (Belgium). Sport Education and Society, 10, 321-341.

Seabra, A. F., Mendonca, D. M., Thomis, M. A., Malina, R. M., \& Maia, J. A. (2007). Sports Participation Among Portuguese Youth 10 to 18 Years. Journal of Physical Activity and Health, 4, 370-380.

Seipple, Ø. (2005). Orker ikke, gidder ikke, passer ikkee? Om frafallet i norsk idrett. Insitutt for samfunnsforskning. Rapport 3. Oslo.

Siedentop, D. (2002). Junior Sport and the Evaluation of Sport Cultures. Journal of Teaching in Physical Education 21, 392-401.

Skille, E. \& Østerås, J. (2011). What does sport mean to you? Fun and other preferences for adolescents' sport participation. Critical Public Health, 21(3), 359-372.

The Swedish Sports Confederation. (2009). Idrotten vill. Idrottsrörelsens verksambetsidé och rikttinjer. [Sports will. Sport associations missions and guidelines]. Stockholm: Riksidrottsförbundet

Trondman, M. (2005) Unga och föreningsidrotten: En studie om föreningsidrottens plats, betydelser och konsekvenser i ungas liv [Youth and club sport]. 2005:9. Stockholm: Ungdomsstyrelsen.

Wall, M. \& Côté, J. (2007). Developmental activities that lead to dropout and investment in sport. Physical Education and Sport Pedagogy, 12(1), 77-87

Wankel, L. M. \& Kreisel, P. S. J. (1985). Factors Underlying Enjoyment of Youth Sport: Sport and Age Group Comparisons. Journal of Sport Psychology. 7, 51-64. 
Weiss, M. R. \& Amorose, A. (2008). Motivational orientations and sport behavior. In Horn, T. (Ed.) Advances in sport psychology, 115-155. Champaign IL Human Kinetics.

Weiss, M. \& Williams, (2004).The Why of Youth Sport Involvement: A Developmental Perspective on Motivational Processes. In Weiss, M. (Ed)Developmental sport and exercise psychology: A lifespan perspective. Morgantown, WV, US: Fitness Information Technology, 223-268.

WHO (World Health Organization). (2002). Health and Development through Physical Activity and Sport. http://apps.who.int/iris/ bitstream/10665/67796/1/WHO_NMH_NPH_PAH_03.2.pdf [Accessed December 11, 2012].

Britta Thedin JAKOBSSON, MA is lecturer and doctoral student at The Swedish School of Sport and Health Sciences (GIH) in Stockholm, Sweden. She earned her Master in Pedagogy in 2004 at Stockholm University with the essay What is health in physical education? - Teachers' talk about health in physical education. Her research areas of interest include experiences of sport participation in organized sport during childhood and youth, as well as aspects of learning process especially health in the school subject physical education and health. She has published in scientific journals, e.g. European Physical Education Review and Physical Education and Sport Pedagogy.

She can be contacted at: britta.thedin.jakobsson@gih.se

\section{Corresponding address:}

Britta Thedin Jakobsson

The Swedish School of Sport and Health Sciences (GIH)

Box 5626 SE-114 86 Stockholm

Phone:+46 8-120 53826

Mobile: +46 70-555 4042

Email: britta.thedin.jakobsson@gih.se

Suzanne LUNDVALL, PhD is currently associate professor at The Swedish School of Sport and Health Sciences (GIH) in Stockholm, Sweden. She earned her PhD in Pedagogy in 2003 at Stockholm University with the thesis: A subject in motion - gymnastics in the PETE program at the Royal Central Institute of Gymnastics/GIH during the period 1944-1992. Her research areas of interest include children's and young's attitudes and experiences of participating in sport and school physical education, as well as aesthetical 
aspects of learning processes in the school physical education. She publishes regularly in scientific journals, e.g. Sport, Education and Society, European Physical Education Review and Physical Education and Sport Pedagogy. She can be contacted at: suzanne. lundvall@gih.se

Karin REDELIUS, PhD is currently pro vice chancellor and associate professor at The Swedish School of Sport and Health Sciences (GIH) in Stockholm, Sweden. She earned her PhD in Pedagogy in 2002 at Stockholm University with the thesis: Coaches in Children's Sport: their Views of Children, Sport and Up-bringing. Her research areas of interest include children's rights in sports as well as issues around assessment and grading in the school subject physical education. She publishes regularly in scientific journals, e.g. Sport, Education and Society, European Physical Education Review and Physical Education and Sport Pedagogy. She can be contacted at: karin.redelius@gih.se 